\title{
SOCIALIZATION OF HEALTH PROTOCOLS TO PREVENT THE SPREAD OF COVID-19 AT PONDOK AREN, SOUTH TANGERANG
}

\author{
Eka Purwa LAKSANA ${ }^{*}$, Nifty FATH ${ }^{2}$, Rummi SIRAIT $^{3}$ \\ Universitas Budi Luhur \\ *eka.purwalaksana@budiluhur.ac.id
}

\begin{abstract}
The Covid-19 pandemic situation has disrupted activities. Corona virus can spread quickly to anyone and can cause death. Therefore, health is an important aspect to pay attention to at this time. Cleanliness is also an important thing that needs attention because it plays an important role in preventing transmission and making the pandemic end soon. However, it turns out that there are still many people who do not understand the importance of cleanliness as a way to maintain health. This form of community service activity, with the aim of increasing public understanding and awareness during the pandemic, especially on Jalan Reformation of RT 05 RW 01, Pondok Aren District, Pondok Aren Village, South Tangerang, emphasizes the importance of maintaining cleanliness during the pandemic. The socialization activities were supported by the construction of simple and automatic hand washing stations and the distribution of masks. In addition, the focus of socialization is also aimed at groups of children. Giving gifts to children is also done as a form of appreciation for using masks in a proper way and getting used to the habit of diligently washing hands. It is hoped that this community service program can achieve the main target which is break the chain of Covid-19 virus spread.
\end{abstract}

Keywords: health protocols, Covid-19, Automatic Hand Washing

\section{BACKGROUND}

Pondok Aren community has a strong and close family relationship. The community is not individualistic, but prioritizes the common good and interests. Even so, it turns out that the awareness of the PondokAren community about the COVID-19 pandemic is very lack. There are some ways transmission of the COVID-19 which often happens. First, hand contact with objects. Objects is a medium that can be a way massive distribution because it is often touched by hand that carries the virus. If people are not taking care hand hygiene, the virus will easily spread.

This community acknowledge that hand washing can prevent the spread of the virus and maintain health, but do not yet have the awareness and commitment to do it as often as possible during a pandemic like this. Moreover, the people there still gather and socialize very often, which should be reduced in frequency because they must practice social distancing or keep a distance from one individual to another, to prevent the spread of the corona virus.

Even in gatherings, the people of Pondok Aren do not fully understand the importance of using masks and how to use masks properly and correctly. There are still Pondok Aren people who don't wear masks even though they have met other people, and quite a lot of Pondok Aren people who use masks but in an inappropriate way to prevent the spread of the corona virus, such as the part of their nose that is not covered by a mask. In connection with the COVID-19 pandemic which has spread throughout Indonesia, the activities of residents have stopped. Therefore, the implementation of community service program follows the advice of the government, namely implementing a program with a health protocol.

Community service program is one of the study activities, which is interdisciplinary as a form of service to the community through the provision of assistance, empowerment, training, counseling, mentoring, and so on to realize the potential of the community, help improve development and the quality of life of the community. Through community service program, academic community are exposed directly to the community, so that there is a mutual give and take between the two.

In this community service activity, socialization activities regarding COVID-19 and recommendations for social distancing and the proper use of masks must be carried out, especially for children (Bulan et al., 2021), (Utama et al., 2020), (Nuraeni et al., 2020). In addition, it is very important for children to taught about the socialization of Covid-19 health protocols (UNICEF, 2020).

Another several community services related to the socialization of COVID-19 such as in (Lette, 2020) has carried out socialization through a brochure in the Fatufeto Village, Kupang. Socialization in houses of worship has also been carried out (Istiatin et al., 2021) and (Damanik et al., 2021). This is important because houses of worship are public facilities that are vulnerable to the spread of COVID-19. Education and socialization are also important to do to reduce public panic as has been done in (Istiatin et al., 2021). The community service program consists of providing automatic hand washing equipment and automatic soap and distributing masks to the public. It is hoped that the community will become more aware of the importance of washing hands and maintaining cleanliness and health during this pandemic.

\section{GENERAL DESCRIPTION OF THE TARGET COMMUNITY}

Geographically, Pondok Aren District is located in the southern part of South Tangerang City, as shown in Figure 1. Pondok Aren is located at $6^{\circ} 15^{\prime} 56.09$ " South Latitude and 10642 ' 58.04" East Longitude. Pondok Aren District has an area of $\pm 29.98 \mathrm{~km}^{2}$. The Pondok Aren sub-district consists of 11 sub-districts, namely: Perigi Baru, Pondok Kacang Barat, Pondok Kacang Timur, Perigi, Pondok Pucung, Pondok Jaya, Pondok Aren, 
Jurangmangu Barat, Jurangmangu Timur, and Pondok Betung. The boundaries of the Pondok Aren sub-district are:

- North side: Tangerang City

- East: South Jakarta City, DKI Jakarta Province

- South: Ciputat and East Ciputat Districts

- On the West: Serpong and North Serpong Districts

Community service activities were carried out in the Pondok Aren sub-district, South Tangerang, Banten. In Pondok Aren, there are 405,316 inhabitants with a composition of 204,849 males and 200,467 females. The population of productive age (aged from 15 to 64 years) in Pondok Aren District is 293,642 people, consisting of 147,997 males and 145,645 females. Meanwhile, the number of people who are already at an unproductive age (0-14 years and more than 65 years) is 111,674 people, consisting of 58,852 men and 48,843 women. The majority of the population in Pondok Aren work as entrepreneurs with an income of around 2 million-4 million Rupiah per month.

The implementation of the community service program was carried out in Pondok Aren District, South Tangerang, more precisely around the housing estate on Jl. Reform RT 05 RW 01, Pondok Jaya Village, Pondok Aren District, South Tangerang, in the area of Aisyah Syamsi Mosque Jl. Iwapi lot.

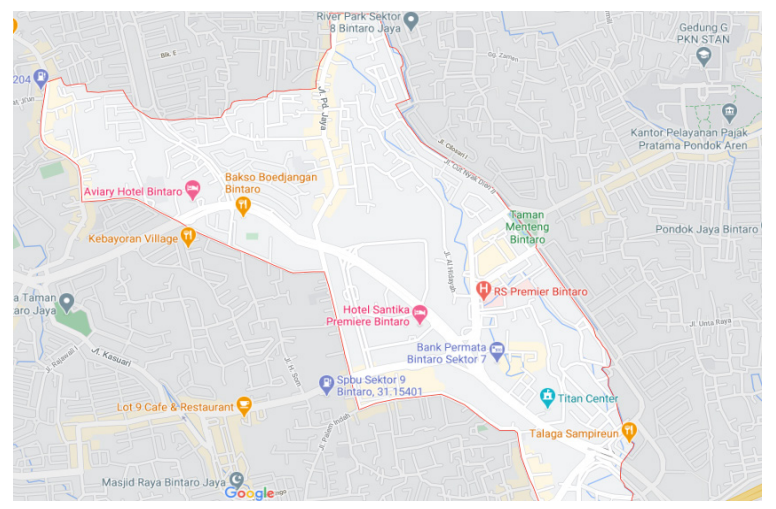

Figure 1. Map of Pondok Aren, South Tangerang

\section{IMPLEMENTATION METHOD}

The community service in Pondok Aren district had several activities such as socialization of the importance of washing hand and wearing mask and create handwashing tools from used materials, with a framework theory as shown in Figure 2.
The socialization activities through some stages as shown in Table 1.

Table 1. Program Implementation Method

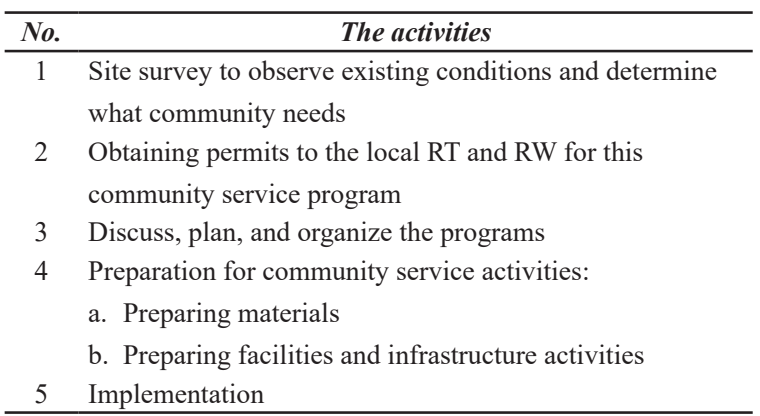

\section{Socialization of the importance of washing hand}

Corona virus can attach easily to human body parts, especially on surfaces that often touch objects such as hands. One way to reduce the risk of infection or break the chain of Covid-19 is to wash your hands with running water and soap. Corona virus molecules are wrapped in protein and fat particles that protect them from water. However, when it encounters to the soap, the fat shield will split, and the virus will also be killed then the water will rinse away the remnants of the virus that soap is difficult to break down.

It is also important to educate young children to be more diligent in washing their hands before and after finishing some activities. They were also taught how to wash their hands properly and correctly.

\section{Create Handwashing Tools from Used Materials}

Handwashing tools is made from recycled materials such as gallons of drinking water. The purpose of this program is to facilitate and increase public awareness of Pondok Aren to get used to maintaining personal hygiene starting from small things, especially during the COVID-19 pandemic.

During this time of pandemic, everyone must wear a mask to carry out routine activities and meet other people. But there are still many residents who do not pay attention to and care about health protocols. Therefore, the distribution of masks to residents in the area was carried out to minimize the emergence of new clusters. It is also for increase awareness and sensitivity of local residents to maintain health and break the chain of the spread of the corona virus.

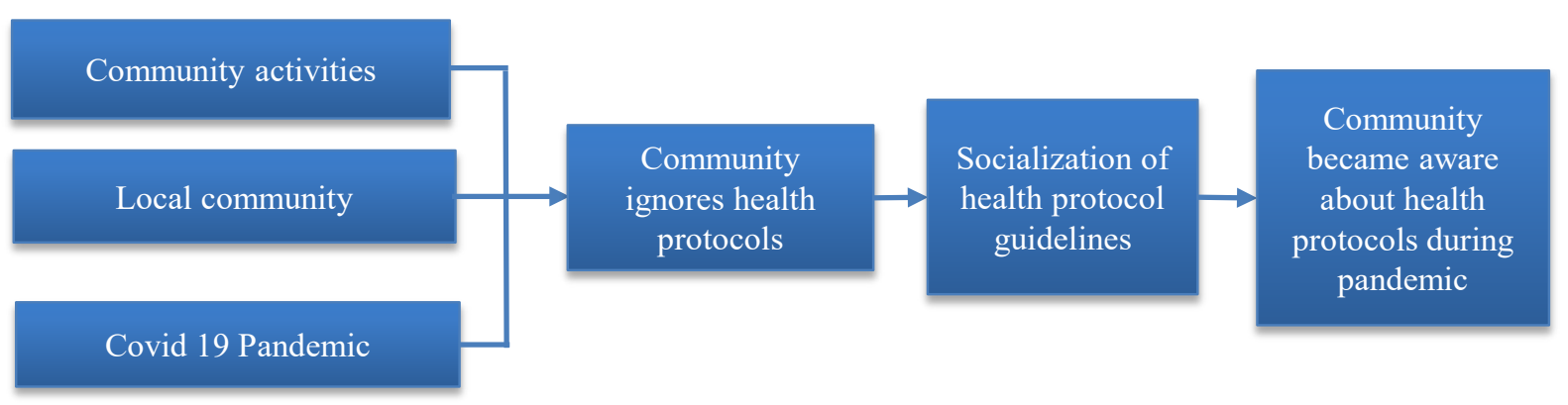

Figure 2. Framework theory 


\section{RESULTS AND DISCUSSION}

In this activity, community leaders in the Pondok Aren area agreed and fully supported the community service work program. The community also showed a positive and open response. The community also dared to provide responses and voice their opinions during the socialization.

In this activity, the community service team carried out activities by making hand washing facilities equipped with hand sensors, aimed at preventing physical touch that could cause the transmission of the Covid-19 virus. In addition, this automatic hand washing place aims to provide facilities around the community so that they can maintain cleanliness anywhere and anytime very easily. The target of this activity is all residents of Pondok Aren, as shown in Figure 3.

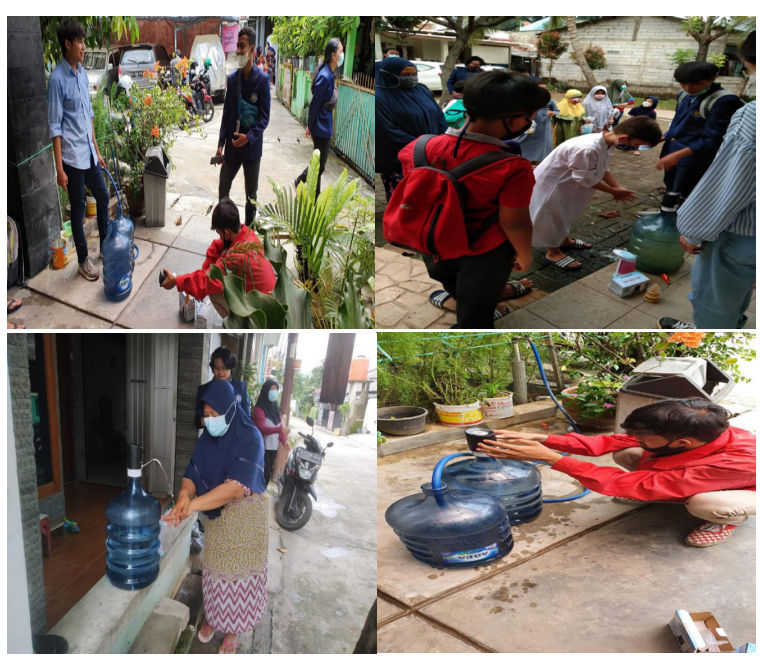

Figure 3. Hand washing socialization with automatic hand wash

In addition, the community service team also distributed masks to the community with the aim of educating the public to continue to comply with health protocols to be able to take care of each other and prevent the spread of Covid-19, as shown in Figure 4. The community service team also educate how to wear masks properly. The benefit achieved from this activity is that the public becomes aware of the importance of health protocols in this pandemic era.

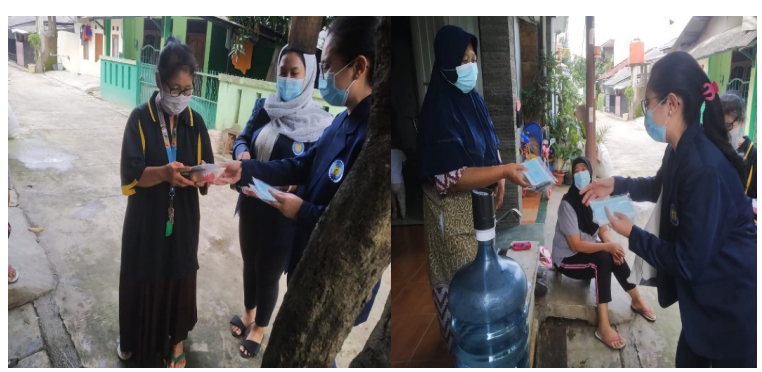

Figure 4. The team explaining how to use a mask properly

Another supporting program carried out in this program is to focus on education about covid-19 to children, and as a form of invitation and a form of appreciation to children who want to learn and care about the dangers of covid-19, a gift is given for the children, as shown in Figure 5.

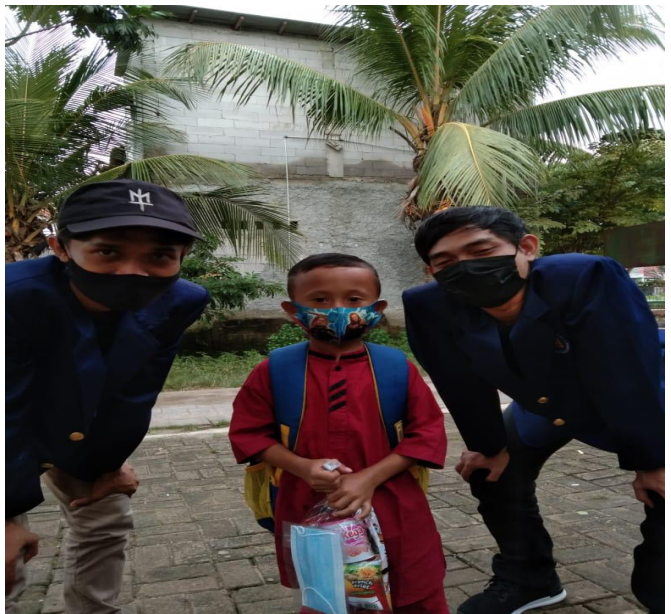

Figure 5. Distribution of gifts to children as a form of appreciation

Some of the supporting factors for the running of this program are described below:

- The positive response from the community for the presence of community service team makes the spirit to carry out activities to the fullest.

- Openness and community participation.

- Attention from the community so that socialization can be conveyed. The existence of cooperation with the surrounding community, so that the socialization activities reach a wider target.

- The community has the courage to respond and voice their opinions during the socialization, so that the socialization runs interactively.

- Availability of facilities that support the implementation of community service programs.

\section{CONCLUSION}

The Covid-19 pandemic situation has disrupted activities. Corona virus can spread quickly to anyone and can cause death. Therefore, health is an important aspect to pay attention to at this time. Cleanliness is also an important thing that needs attention because it plays an important role in preventing transmission and making the pandemic end soon. However, it turns out that there are still many people who do not understand the importance of cleanliness as a way to maintain health. Community service activity, with the aim of increasing public understanding and awareness during the pandemic, especially on Jl. The reformation of RT 05 RW 01, Pondok Aren District, Pondok Aren Village, South Tangerang, emphasizes the importance of maintaining cleanliness during the pandemic. This program is getting fully support from the local community.

\section{REFERENCES}

Bulan, T. P. L., Yusnawati, \& Mauliza. (2021). Sosialisasi Penggunaan Dan Pembuatan Hand Sanitizerdalam Mengantisipasi Dampak Corona Virus Disease(Covid-19). Global Science Society: Jurnal Ilmiah Pengabdian Kepada Masyarakat, 3(1), 24-30. 
Damanik, R. K., Gulo, A. R. B., \& Simanjuntak, E. Y. (2021). UPAYA PENCEGAHAN PENULARAN COVID-19 MELALUI SOSIALISASI DAN PENYEMPROTAN RUMAH IBADAH. JURNAL KREATIVITAS PENGABDIAN KEPADA MASYARAKAT (PKM), 4(2), 425-433.

Istiatin, Marwati, F. S., \& AY, B. (2021). Sosialisasi dan Edukasi Program Penanganan dan Pencegahan Penyebaran Covid-19 Guna Meredam Kepanikan Sosial di Wilayah Desa Gentan. Jurnal BUDIMAS, 03(2), 260-269.

Lette, A. R. (2020). Sosialisasi Pencegahan COVID-19 Melalui Brosur di RT 20/RW 07 Kelurahan Fatufeto Kota Kupang. JPKMI (Jurnal Pengabdian Kepada Masyarakat Indonesia), 1(4), 236-242. https://doi. org/10.36596/jpkmi.v1i4.113
Nuraeni, I., Bachtiar, R. A., Karimah, I., \& Hadiningsih, N. (2020). Pencegahan Covid-19 Melalui Sosialisasi Penggunaan Dan Pembagian Masker Di Kota Tasikmalaya Dan Kabupaten Tasikmalaya. 73-79.

UNICEF. (2020). Psychosocial Support for Children during COVID-19. Child Line India Foundation, 2-81. https://www.unicef.org/india/media/3401/ file/PSS-COVID19-Manual-ChildLine.pdf

Utama, D. P., Kartikasari, D., Hati, S. W., Hendrawan, B., Handayani, Y., Wirawan, A., Mulyana, A. E., Syafrina, M., Puspitasari, A., \& Harlan, F. B. (2020). Sosialisasi Antisipasi Penyebaran Covid-19 melalui Buku Panduan dan Vidio Animasi Sebagai Penunjang Stabilitas Perekonomian Masyarakat di Kota Batam. JURNAL PENGABDIAN KEPADA MASYARAKAT (AbdiMas), 2(2), 86-98. https://doi. org/10.30871/abdimas.v2i2.2218 